\title{
Interaksi Hubungan antara Foreign Direct Investment dan Pertumbuhan Ekonomi
}

\author{
Khoirul Ifa ${ }^{1}$, Neny Tri Indrianasari ${ }^{2}$, Nawangsih ${ }^{3}$ \\ Program Studi Akuntansi, STIE Widya Gama Lumajang ${ }^{12}$ \\ Program Studi Manajemen, STIE Widya Gama Lumajang ${ }^{3}$ \\ Email:khoirul.ifa@gmail.com
}

https://doi.org/10.30741/wiga.v9i2.446

I N F O A R T IKE L

Tanggal masuk :

31 Agustus 2019

Tanggal Revisi :

9 September 2019

Tanggal Diterima :

30 September 2019

\section{A B S T R A K}

Di Negara ASEAN 5 yaitu Indonesia, Vietnam, Thailand, Filiphina, dan Malaysia mempunyai kultur yang hampir sama, dari sisi sosial dan ekonomi ke 5 negara tersebut mempunyai keterkaitan antar satu negara dengan yang negara lain, sehingga dimungkinan arus investasi asing mempunyai hubungan yang erat dengan pertumbuhan ekonomi. Penelitian ini bertujuan untuk untuk mengetahui hubungan antara Foreign Direct Investment (FDI) dan Pertumbuhan Ekonomi di Negara ASEAN 5 Periode Tahun 1986-2017. Penelitian ini merupakan penelitian hubungan dua arah antara variabel independen dan variabel dependen yang saling timbal balik. Jenis data yang digunakan adalah data time series tahun 1981-2017. Sumber data di peroleh dari World Bank. Teknik analisis data menggunakan analisis Granger Causality untuk melihat hubungan 2 arah, dan analisis VAR (Vector Auto Regression) dengan melihat implus respon factor untuk data yang tidak stasioner menggunakan analisis VECM (Vector Error Correction Model). Hasil penelitian menyebutkan Berdasarkan uji Granger Causality tidak terdapat hubungan antara FDI terhadap GDP dan sebaliknya antara GDP terhadap FDI, Berdasar uji VECM terdapat hubungan antara FDI terhadap GDP.

Kata kunci : FDI, Pertumbuhan Ekonomi, VAR dan VECM

\begin{abstract}
A B S T R A C T
In ASEAN 5 countries namely Indonesia, Vietnam, Thailand, the Philippines and Malaysia have almost the same culture, in terms of social and economic aspects, the 5 countries have links between one country and another, so it is possible that the flow of foreign investment has a close relationship with economic growth. This study aims to determine the relationship between Foreign Direct Investment (FDI) and Economic Growth in ASEAN 5 Periods 1986-2017. This research is a two-way relationship research between the independent variable and the dependent variable that are reciprocal. The type of data used is the 1986-2017 time series data. Sources of data obtained from the World Bank. Data analysis technique uses Granger Causality analysis to see the 2-way relationship, and VAR (Vector Auto Regression) analysis by looking at the implus response factor for nonstationary data using VECM (Vector Error Correction Model) analysis. The results of the study state that based on the Granger Causality test there is no relationship between FDI and GDP and vice versa between GDP and FDI. Based on the VECM test there is a relationship between FDI and GDP.
\end{abstract}

Keywords: FDI, Economic Growth, VAR and VECM 


\section{PENDAHULUAN}

Pertumbuhan ekonomi diyakini merupakan tolak ukur keberhasilan suatu negara, karena merupakan proses kenaikan output barang dan jasa yang akan menaikkan pendapatan nasional. Pertumbuhan ekonomi didukung oleh kenaikan dari berbagai variabel lain seperti investasi dan perdagangan internasional. Adapun faktor pendorong pertumbuhan ekonomi menurut Todaro, 2003 diwujudkan dalam tiga komponen utama, pertama, akumulasi modal yang meliputi semua bentuk dan jenis investasi baru yang ditanamkan dalam tanah, peralatan fisik, dan modal manusia. Kedua, pertumbuhan penduduk yang selanjutnya akan menambah jumlah angkatan kerja. Ketiga kemajuan teknologi yang dalam pengertian sederhananya terjadi karena ditemukannya cara-cara baru atau perbaikan atas cara-cara lama. Dalam hal ini investasi merupakan salah satu pendorong pertumbuhan ekonomi, pernyataan tersebut juga didukung oleh Lamsiraroj dan Ulubasoglu, 2015 yang menunjukkan terdapat pengaruh positif antara FDI dengan pertumbuhan ekonomi di 140 negara pada periode 1970-2009, pengaruh yang paling kuat terdapat di negara sedang berkembang, sedangkan menurut Almfraji dan Almsafir, 2014 bahwa dalam jangka panjang terdapat hubungan antara FDI dengan Pertumbuhan Ekonomi di Negara Qatar, selain itu terdapat pengaruh positif FDI terhadap pertumbuhan ekonomi di negara Qatar.

Pada hakikatnya, rata-rata pertumbuhan ekonomi berbeda-beda setiap negara. Pada beberapa negara Asia, seperti Cina, Hongkong, Singapura, Korea Selatan, dan Taiwan rata-rata pendapatan riil penduduknya meningkat sekitar $6 \%$ per tahun dalam kurun waktu lima puluh tahun terakhir,(Mankiw, 2014 : 39). Di negara yang tergabung dalam ASEAN laju pertumbuhan ekonomi berbeda antar negara walaupun secara kultur negara-negara tersebut hampir sama.

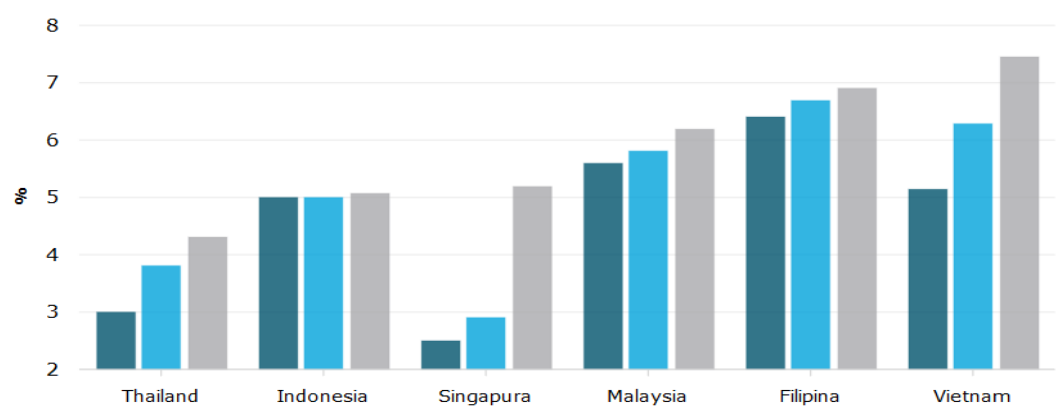

Gambar 1. Pertumbuhan Ekonomi di 6 Negara ASEAN Kuartal I-III Tahun 2017

Sumber : Tradingeconomics, 2017

Beberapa negara ASEAN mengalami percepatan pertumbuhan ekonomi pada sepanjang tahun 2017. Pada kuartal III perekonomian Vietnam dan Filipina melaju kencang mengalahkan tiongkok, namun perekonomian Indonesia mengalami stagnasi pada kuartal I,II dan III. Pertumbuhan ekonomi Vietnam mencapai 7,46\% pada kuartal III, lebih besar pada kuartal I dan kuartal II yakni sebesar 5,15\% dan 6,28\%, dibandingkan negara ASEAN lain pertumbuhan ekonomi Vietnam tertinggi, kondisi tersebut disebabkan oleh faktor ekspor utama dari industri milik asing. Pertumbuhan ekonomi yang ditopang investasi dianggap akan meningkatkan produktivitas suatu negara atau daerah. Investasi adalah pembelian barang yang nantinya akan digunakan untuk memproduksi lebih banyak barang dan jasa (Mankiw, 2006:12). FDI juga merupakan penyokong pertumbuhan ekonomi suatu negara. Ada kausalitas granger antara FDI dan GDP (Tekin, 2012; Lamsiraroj dan Ulubasoglu, 2015; Ibrahiem, 2015; Khatun dan Ahamad, 2015; Khatun dan Ahamad, 2015; Abdouli dan Hammami, 2016).

Penelitian Sunde, 2017 tentang "Investasi langsung asing dan pertumbuhan ekonomi: Analisis ADRL dan kausalitas di Negara Afrika Selatan”. Hasil penelitiannya menunjukkan bahwa baik investasi langsung maupun ekspor asing memacu pertumbuhan ekonomi. Analisis kausalitas 
menunjukkan terdapat kausalitas searah antara pertumbuhan ekonomi dan asing Investasi langsung dan sebaliknya dari investasi asing langsung ke pertumbuhan ekonomi. Sementara Abbes, dkk, 2015 tentang "Interaksi hubungan antara FDI dan Pertumbuhan Ekonomi: model data panel dinamis dan kointegrasi " mengindikasikan adanya hubungan searah antara FDI dan GDP di 65 negara yakni negara kawasan asia dan negara maritime, negara timur tengah, negara bagian amerika utara, negara amerika latin, negara eropa, negara afrika utara, dan negara afrika tengah pada periode analisis $1980-2010$.

Penelitian dilakukan oleh Diby, 2014 tentang "Dampak investasi asing langsung terhadap pertumbuhan ekonomi di Afrika: selama tiga dekade menggunakan analisis data panel" menunjukkan ada pengaruh positif dan signifikan antara FDI dengan pertumbuhan ekonomi dinegara bagian Afrika selama periode bunga. Namun ada dampak negatif FDI terhadap pertumbuhan ekonomi selama periode tahun 1980-1994 dan memiliki dampak positif selama periode 1995-2009. Hasil penelitian yang berbeda oleh Belloumi, 2014 tentang "Hubungan antara perdagangan, FDI dan pertumbuhan ekonomi di Tunisia: Menggunakan Model Autoregressive Distribusion Lag “ menunjukkan bahwa tidak ada hubungan yang signifikan dari FDI ke ekonomi pertumbuhan, dari pertumbuhan ekonomi ke FDI, dari perdagangan ke pertumbuhan ekonomi dan dari pertumbuhan ekonomi ke perdagangan dalam jangka pendek di Negara Tunisia Tahun 19702008. Sedangkan Nistor, 2014 dalam penelitiannya tentang "FDI dan Pertumbuhan Ekonomi : Studi kasus pada Negara Romania" menunjukkan terdapat pengaruh positif FDI inflows terhadap pertumbuhan ekonomi dan terdapat hubungan positif antara FDI dan pertumbuhan ekonomi periode tahun 1990-2012 di Negara Romania.

Keadaan yang berbeda ditunjukkan pada kajian yang dilakukan oleh Dritsaki dan Stiakakis, 2014 tentang "FDI, Ekspor, dan Pertumbuhan Ekonomi di Kroasia: Analisis Time Series" menunjukkan bahwa investasi asing langsung tidak mengakibatkan pertumbuhan di Kroasia, baik dalam jangka pendek maupun jangka panjang selama periode tahun 1994-2012. Temiz dan Gokmen, 2014 pada kajian yang berjudul "FDI inflow sebagai operasi bisnis internasional oleh perusahaan multinasional dan pertumbuhan ekonomi: Sebuah studi empiris pada Negara Turki" juga menyebutkan tidak ada hubungan yang signifikan antara FDI inflow dan pertumbuhan ekonomi di Turki baik dalam jangka pendek maupun jangka panjang. Berdasarkan gab analysis diatas maka perumusan masalah penelitian ini adalah Apakah ada hubungan antara Foreign Direct Investment (FDI) dan Pertumbuhan Ekonomi (GDP) dan sebaliknya apakah ada hubungan antara Pertumbuhan Ekonomi (GDP) dan Foreign Direct Investment (FDI) di negara ASEAN 5 periode tahun 1981-2017 ?. Tujuan penelitian ini adalah mengetahui hubungan antar variabel FDI dan Pertumbuhan Ekonomi dan sebaliknya

\section{METODE PENELITIAN}

Penelitian ini merupakan penelitian hubungan dua arah antara variabel independen dan variabel dependen yang saling timbal balik, maksudnya satu variabel dapat menjadi sebab dan juga akibat terhadap variabel lainnya, demikian pula sebaliknya. Tujuan penelitian ini bersifat eksplanatori (explanatory research) dimana penelitian eksplanatori merupakan jenis penelitian yang menjelaskan hubungan kausal antara satu variabel dengan variabel lainnya melalui pengujian hipotesis. Objek dalam penelitian ini adalah Negara ASEAN 5 yaitu Indonesia, Malaysia, Thailand, Vietnam dan Filipina dengan melihat hubungan antara Foreign Direct Investment, dan Pertumbuhan Ekonomi. Alasan memilih objek tersebut karena karakteristik dan kultur sosial budaya yang hampir sama, disamping ini terdapat keterkaitan sektor ekonomi antar satu negara dengan negara lain.

Teknik pengumpulan data menggunakan studi dokumentasi dengan mengumpulkan data sekunder, mencatat, dan mengolah data yang berkaitan dengan penelitian ini. Menurut Azwar (2001 :91) Data sekunder biasanya berwujud data dokumentasi atau data laporan yang telah tersedia. Data yang di gunakan meliputi : Foreign Direct Investment (FDI), ekspor, pengeluaran pemerintah dan 
Pertumbuhan Ekonomi (GDP). Sedangkan jenis data yang digunakan adalah data time series tahun 1981-2017. Sumber data di peroleh dari World Bank. Teknik analisis data penelitian ini menggunakan model VAR dan VECM. Menurut Greene, 2002 Bentuk persamaan VAR telah banyak berubah namun tidak hanya bentuk persamaan yang berubah, variabel dalam persamaan telah berubah juga, VAR tidak hanya berbentuk beberapa model struktural namun juga bertujuan untuk menganalisis dan meramalkan aktivitas ekonomi makro dan menelusuri pengaruh perubahan kebijakan dan stimulus eksternal pada ekonomi. Selain peramalan, VAR telah digunakan untuk dua fungsi utama, pengujian Granger kausalitas dan mempelajari efek dari kebijakan melalui implus respon factor dan variance decomposition.

Menurut Gujarati (1995) terdapat beberapa keunggulan metode VAR diantaranya : (1) Metode sederhana; tidak perlu khawatir tentang menentukan variabel yaitu yang mana endogen dan mana yang eksogen. Semua variabel dalam VAR adalah endogenous. (2) Estimasi sederhana; yaitu, metode OLS bisa diterapkan untuk setiap persamaan secara terpisah. (3) Peramalan (Forcasting) dengan metode ini dalam banyak kasus lebih baik dari beberapa model persamaan simultan. Vector Error Correction Model (VECM) adalah pengembangan model VAR untuk analisis lebih mendalam jika kita ingin mempertimbangkan adanya perilaku data yang tidak stasioner (Ekananda, 2016). Perbedaaan utama persamaan kointegrasi pada VECM diantaranya : 1. Persamaan kointegrasi yang dihasilkan adalah bentuk restriksi dari model VAR, dimana model VAR mengasumsikan bahwa terdapat hubungan dinamis dari beberapa variabel (vector) yang saling berkaitan. 2. Persamaan kointegrasi yang dihasilkan diperoleh dari metode johansen, dimana kointegrasi ditimbulkan dari pengukuran nilai eigen beberapa kombinasi variabel. 3 . Susunan persamaan kointegrasi ditentukan oleh urutan variabel pada model VECM. 4. Susunan persamaan kointegrasi menunjukkan hubungan antar persamaan dan antar variabel secara simultan dinamis. 5. Susunan persamaan kointegrasi menunjukkan hubungan antar persamaan dan antar variabel secara simultan dinamis. 6. Penyusunan persamaan kointegrasi harus dimulai dari penyusunan VECM yang sesuai dengan teori ekonomi di awal penelitian. Persamaan kointegrasi yang terbentuk adalah konsekuensi penyusunan teori dan model VECM yang disusun sebelumnya (Ekananda, 2016).

\section{HASIL DAN PEMBAHASAN}

Pertumbuhan ekonomi di kelima negara ASEAN mengalami fluktuasi. Sejak tahun 1981-1996 laju pertumbuhan ekonomi di negara ASEAN 5 mengalami pertumbuhan yang positif, namun sejak tahun 1997-1998 di beberapa negara ASEAN khususnya Indonesia, Malaysia, Filipina, Thailand dan Vietnam mengalami pertumbuhan ekonomi yang negative, hal ini disebabkan krisis keuangan yang terjadi dibeberapa negara asia, krisis keuangan bermula di negara Thailand karena adanya jatuhnya nilai mata uang bath yang akhirnya berimbas kebeberapa negara asia lain. Dampak krisis ekonomi tahun 1997-1998 paling dirasakan yaitu oleh negara Indonesia, hal ini terlihat pada kondisi pertumbuhan yang turun drastis dengan nilai pertumbuhan negative dibandingkan negara ASEAN lainnya yaitu Malaysia, Filipina, Thailand dan Vietnam.

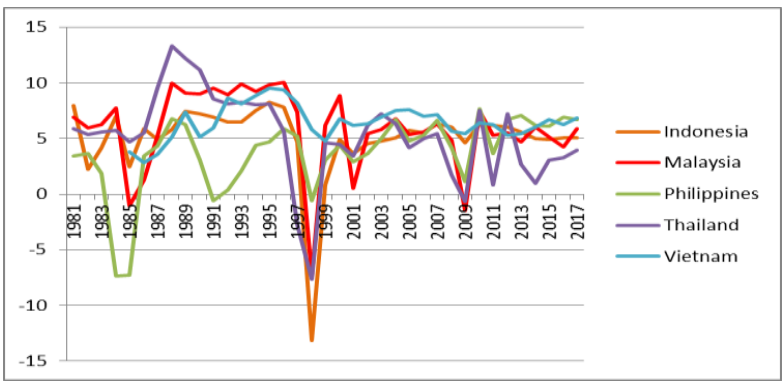

Gambar 2. Pertumbuhan Ekonomi di Negara ASEAN 5

Sumber : World Bank, 2017 
Tahun 1999 pertumbuhan ekonomi menunjukkan perkembangan yang stabil dibandingkan tahuntahun sebelumnya, pergerakan pertumbuhan ekonomi sudah tumbuh positif di negara ASEAN 5. Namun pertumbuhan ekonomi melemah kembali setelah adanya krisis global pada tahun 2008. Krisis ekonomi global yang terjadi pada tahun 2008 sebenarnya bermula pada krisis ekonomi Amerika Serikat yang lalu menyebar ke negara-negara lain di seluruh dunia, termasuk negara ASEAN seperti, Malaysia, Thailand, Filipina, Vietnam dan Indonesia.Krisis ekonomi global tahun 2009 diawali di negara Amerika yang disebabkan adanya dorongan untuk konsumsi (propincity to Consume). Rakyat Amerika hidup dalam konsumerisme di luar batas kemampuan pendapatan yang diterimanya. Mereka hidup dalam hutang, belanja dengan kartu kredit, dan kredit perumahan. Akibatnya lembaga keuangan yang memberikan kredit tersebut bangkrut karena kehilangan likuiditasnya, karena piutang perusahaan kepada para kreditor perumahan telah digadaikan kepada lembaga pemberi pinjaman. Pada akhirnya perusahaan -perusahaan tersebut harus bangkrut karena tidak dapat membayar seluruh hutang-hutangnya yang mengalami jatuh tempo pada saat yang bersamaan. Runtuhnya perusahaan-perusahaan finansial tersebut mengakibatkan bursa saham Wall Street menjadi tak berdaya, perusahaan-perusahaan besar tak sanggup bertahan. Negara ASEAN 5 yang paling terkena imbas krisis ekonomi global tahun 2009 yaitu negara Malaysia dan Thailand. Sampai tahun 2017 pertumbuhan ekonomi di negara ASEAN 5 mengalami laju pertumbuhan positif walaupun perkembangannya fluktuatif.

Perkembangan aliran modal masuk asing di beberapa negara ASEAN 5 berbeda-beda, sejak tahun 1981-1996 kondisi FDI mengalami pertumbuhan yang pesat terutama di negara Vietnam dan Malaysia, seperti yang kita ketahui Vietnam merupakan negara komunis yang paling banyak diincar oleh beberapa investor asing, disamping karena kisah sukses perusahaan sepatu raksasa seperti adidas dan nike, Vietnam juga terkenal dengan teknologi tinggi terbukti intel telah menanamkan usahanya di negara tersebut sejak tahun 2010 disusul LG Group dan Samsung yang menuai sukses berinvestasi di Vietnam.

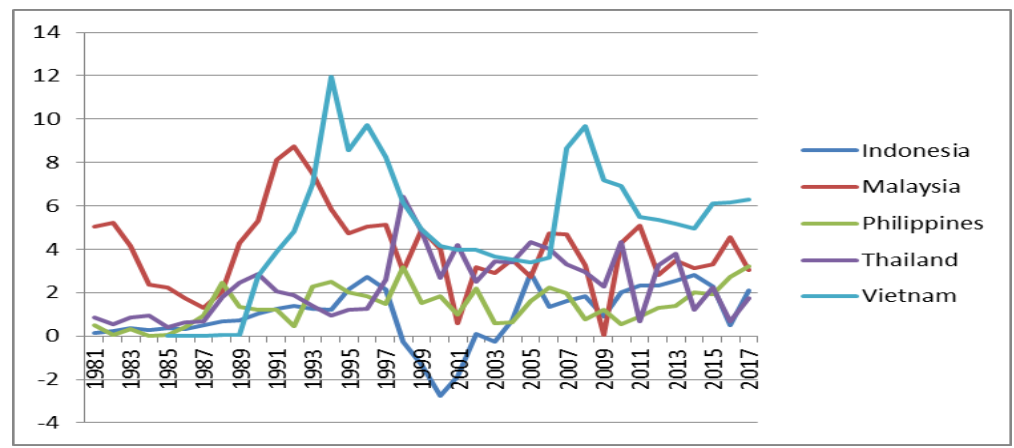

Gambar 3. FDI di Negara ASEAN 5

Sumber : World Bank, 2017

Pertumbuhan FDI yang paling memprihatikankan yaitu negara Indonesia pada tahun 1997-1998, dampak krisis moneter sangat dirasakan di Indonesia hal ini ditandai dengan melemahnya nilai tukar rupiah terhadap dollar AS yang menyebabkan Orang-orang kaya Indonesia, baik pejabat pribumi dan etnis Cina, sudah sejak tahun lalu bersiap-siap menyelamatkan harta kekayaannya ke luar negeri mengantisipasi ketidak stabilan politik dalam negeri. Sejak awal Desember 1997 hingga awal Mei 1998 telah terjadi pelarian modal besar-besaran ke luar negeri karena ketidak stabilan politik seperti isu sakitnya Presiden dan Pemilu (World Bank, 1998: 1.4, 1.10).

Keterbukaan perdagangan merupakan salah satu tolak ukur kesiapan suatu negara menjalin spesialisasi produk di bidang perdagangan,menurut teori perdagangan adam smith dan david ricardo setiap negara memiliki keunggulan komparatif dan keunggulan advantage sehingga setiap 
negara tentunya akan berspesialisasi. Gambar 4. dibawah menunjukkan negara Vietnam dan Malaysia memiliki nilai keterbukaan perdagangan yang tinggi dibandingkan dinegara ASEAN 5 yang lain. Disamping karena kedua negara tersebut merupakan tujuan investor asing, negara tersebut merupakan negara dengan pertumbuhan ekonomi yang lebih pesat.

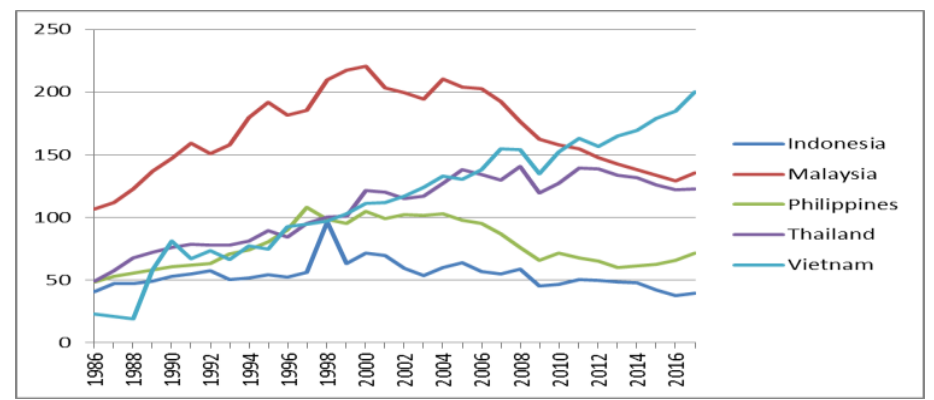

Gambar 4. Trade Oppennes di Negara ASEAN 5

Sumber : World Bank, 2017

\section{Hasil Analisis}

Berdasarkan hasil estimasi uji chow dari Tabel 1 menunjukkan bahwa nilai probabilitas ChiSquare $(0,4457)$ lebih besar dibandingkan dengan probabilitas kritis $(\alpha=5 \%$ atau 0,05$)$. Artinya menunjukkan bahwa Hipotesis nol (H0) diterima dan H1 ditolak. Dengan demikian diketahui bahwa model kurang baik dan tidak tepat menggunakan analisis regresi data panel model Fixed Effect. Pengujian penentuan model terbaik dilanjutkan dengan menggunakan Hausman Test.

Tabel 1. Hasil Pengujian Model PLS, FEM dan REM

\begin{tabular}{llll}
\hline Variabel & Panel Least Square & Fixed Effect Model & Random Effect Model \\
\hline Trade & -0.018870 & -0.027422 & -0.018870 \\
& $(0.0070)^{*}$ & $(0.0417)^{*}$ & $(0.0072)^{*}$ \\
FDI & 1.059017 & 0.998433 & 1.059017 \\
& $(0.0005)^{*}$ & $(0.0000)^{*}$ & $(0.0000)^{*}$ \\
Adjusted R-square & 0.227080 & 0.223281 & 0.227080 \\
F-statistic & 0.000002 & 0.000018 & 0.000002 \\
Uji Chow & 1.616356 & & \\
Prob. & 0.4457 & & \\
Uji Hausman & 1.545142 & & \\
Prob & 0.4618 & & \\
LM & 29.14296 & & \\
Prob. & $0.0000^{*}$ & & \\
Sumber $:$ Hasil & Elat & & \\
\hline
\end{tabular}

Sumber : Hasil Olah Eviews 7

Berdasarkan uji hausman pada tabel 1 diketahui nilai probabilitas Chi-Square $(0,4618)$ lebih besar dibandingkan dengan probabilitas kritis $(\alpha=5 \%$ atau 0,05$)$. Artinya menunjukkan bahwa Hipotesis nol (H0) diterima dan H1 ditolak. Dengan demikian diketahui bahwa model kurang baik dan tidak tepat menggunakan analisis regresi data panel model random Effect. Pengujian penentuan model terbaik dilanjutkan dengan menggunakan LM Test.

Berdasarkan LM test pada tabel 1 diketahui nilai probabilitas Chi-Square $(0,000)$ lebih kecil dibandingkan dengan probabilitas kritis $(\alpha=5 \%$ atau 0,05$)$. Artinya menunjukkan bahwa Hipotesis 
nol (H0) ditolak dan H1 diterima. Dengan demikian diketahui bahwa model telah baik dan tepat menggunakan analisis regresi data panel model random Effect.

Uji stasioneritas digunakan untuk melihat apakah dalam variabel penelitian memiliki akar unit atau tidak memiliki akar unit. Data stasioner tidak ditemukan akar-akar unit sedangkan data tidak stasioner memiliki akar unit. Pengujian akar unit menggunakan Augmented dickey fuller test, data stasioner harus memiliki nilai t statistic pada ADF lebih besar dari nilai kritis (critical values).

Berdasarkan hasil pengujian akar unit (unit root) pada tabel 2 dibawah menunjukkan bahwa variabel GDP, FDI dan TRADE dalam penelitian tidak stasioner pada data level terlihat nilai Probabilitas masih lebih besar dari nilai kritik $\alpha=0,05$. Hasil output tersebut menunjukkan bahwa data tidak stasioner pada tingkat data level.

Tabel 2. Hasil Unit Root Test

\begin{tabular}{llll}
\hline Levin, Lin, Chu (LLC) & & & \\
\hline Tingkat & GDP & TRADE & FDI \\
Level & $0.0002^{*}$ & 0.1002 & 0.2628 \\
1st Difference & $0.0007^{*}$ & $0.0071^{*}$ & $0.0000^{*}$ \\
2nd Difference & $0.0000^{*}$ & $0.0000^{*}$ & $0.0000^{*}$ \\
Im Pesaran, Shin (IPS) & & & \\
Tingkat & GDP & TRADE & FDI \\
Level & $0.0002^{*}$ & 0.7722 & 0.743 \\
1st Difference & $0.0000^{*}$ & $0.0000^{*}$ & $0.0000^{*}$ \\
2nd Difference & $0.0000^{*}$ & $0.0000^{*}$ & $0.0000^{*}$ \\
Fisher- Augment Dickey Fuller (F-ADF) & & \\
Tingkat & GDP & TRADE & FDI \\
Level & $0.0008^{*}$ & 0.8715 & 0.1033 \\
1st Difference & $0.0000^{*}$ & $0.0000^{*}$ & $0.0000^{*}$ \\
2nd Difference & $0.0000^{*}$ & $0.0000^{*}$ & $0.0000^{*}$ \\
Fisher- Phillip Perron (Fisher-PP) & & \\
Tingkat & GDP & TRADE & FDI \\
Level & $0.0001^{*}$ & 0.5094 & 0.0417 \\
1st Difference & $0.0000^{*}$ & $0.0000^{*}$ & $0.0000^{*}$ \\
2nd Difference & $0.0000^{*}$ & $0.0000^{*}$ & $0.0000^{*}$ \\
\hline Kerangan: & &
\end{tabular}

Keterangan: *Stasioner $(\alpha=5 \%)$

Sumber : Hasil Olah Eviews 7

Sedangkan berdasarkan hasil pengujian akar unit menggunakan data first difference terlihat bahwa variabel GDP, FDI dan TRADE dalam penelitian telah stasioner karena nilai Probabilitas lebih kecil dari nilai kritik $\alpha=0,05$ masing-masing 0,0000>0,05. Hasil output tersebut menunjukkan bahwa data stasioner.

Untuk melihat data penelitian terdapat kointegrasi atau tidak yaitu dengan menggunakan Johansen Cointegration Test. Berikut ini merupakan Hasil Johansen Cointegration Test menggunakan panjang lag 1 dengan data fist difference. Jika nilai Trance Statistic lebih besar dari Critical Value maka persamaan tersebut terkointegrasi dan sebaliknya jika nilai Trance Statistic lebih kecil dari Critical Value maka persamaan tersebut tidak terkointegrasi, atau nilai probabilitas ADF > nilai critical value 5\%, dalam model VAR persamaan yang digunakan adalah persamaan yang tidak terkointegrasi. 
Tabel 3. Hasil Uji Kointegrasi

\begin{tabular}{ll}
\hline Prob. ADF & Keterangan \\
\hline 0.0001 & Terkointegrasi \\
\hline
\end{tabular}

Sumber : Hasil Olahan Eviews 7

Hasil Johansen Cointegration Test pada Tabel 3 diatas menunjukkan persamaan kointegrasi dengan nilai Probabiltas ADF lebih kecil dari Critical Value $(0,0001<0,05)$ maka dalam penelitian ini menggunakan model Vector Error Correction Model (VECM).

Untuk mentukan panjang lag yang optimal menggunakan nilai kriteria Akaike Information Criterion (AIC). Nilai AIC terkecil yang digunakan dalam penentuan lag yang optimal. Berdasarkan Tabel 5.4 dibawah terlihat bahwa nilai Akaike Information Criterion (AIC) terkecil terletak pada lag 2, maka panjang lag yang optimal yaitu 2 dengan nilai AIC sebesar 15.62982.

Tabel 4. Hasil Penentuan Panjang Lag Optimal

\begin{tabular}{cc}
\hline Lag & AIC \\
\hline 0 & 19.38927 \\
1 & 15.63257 \\
2 & $15.62982 *$ \\
3 & 15.71951 \\
4 & 15.89785 \\
5 & 16.02985 \\
6 & 16.13867 \\
7 & 16.17018 \\
8 & 16.29902 \\
\hline
\end{tabular}

Sumber : Hasil Olahan Eviews 7

Berdasarkan hasil uji Granger Causality pada tabel 5 dibawah menunjukkan nilai probalilitas lebih besar dari sig 0,005 baik variabel GDP, FDI dan TRADE, artinya tidak ada hubungan dua arah antara GDP terhadap FDI begitupun sebaliknya, tidak ada hubungan dua arah atara TRADE terhadap FDI begitupun sebaliknya, dan tidak ada hubungan dua arah TRADE terhadap GDP dan sebaliknya.

Tabel 5. Hasil Uji Granger Causality

\begin{tabular}{lccc}
\hline \multicolumn{1}{c}{ Null Hypothesis: } & Obs & F-Statistic & Prob. \\
\hline GDP does not Granger Cause FDI & 90 & 1.54031 & 0.2202 \\
& & 0.51103 & 0.6017 \\
FDI does not Granger Cause GDP & & & \\
& 90 & 1.92462 & 0.1522 \\
TRADE does not Granger Cause FDI & & 3.07619 & 0.0513 \\
FDI does not Granger Cause TRADE & 90 & 0.30541 & 0.7376 \\
& & 2.86166 & 0.0627 \\
TRADE does not Granger Cause GDP & 90 & & \\
GDP does not Granger Cause TRADE & & &
\end{tabular}

Sumber : Hasil Olah Eviews 7

Karena dengan pengujian Granger Causality tidak ada hubungan antara FDI dan GDP begitupun sebaliknya maka estimasi diteruskan menggunakan metode VECM untuk melihat hubungan 
jangka panjang antara FDI dan GDP, TRADE dan GDP. Estimasi VECM digunakan untuk melihat pergerakan FDI, GDP dan TRADE di masa lalu, selain itu model VAR maupun VECM tidak hanya berbentuk struktural namun bertujuan untuk menganalisis dan meramalkan aktivitas ekonomi makro dan menelusuri pengaruh perubahan kebijakan dan stimulus eksternal pada ekonomi. Hasil uji kointegrasi diatas bahwa setiap variabel terkointegrasi maka model yang digunakan adalah model VECM.

Selanjutnya untuk mengetahui shock (goncangan) setiap variabel terhadap variabel-variabel lain menggunakan Implus Respons Factor (IRF). Gambar dibawah ini menunjukkan periode dimana satu periode mewakili satu bulan. Penelitian ini menggunakan jangka waktu 24 bulan, sehingga periode yang digunakan dalam uji IRF tersebut sebanyak 24 periode. Berikut merupakan hasil estimasi IRF berdasarkan hubungan masing-masing variabel (Lihat Gambar 5)

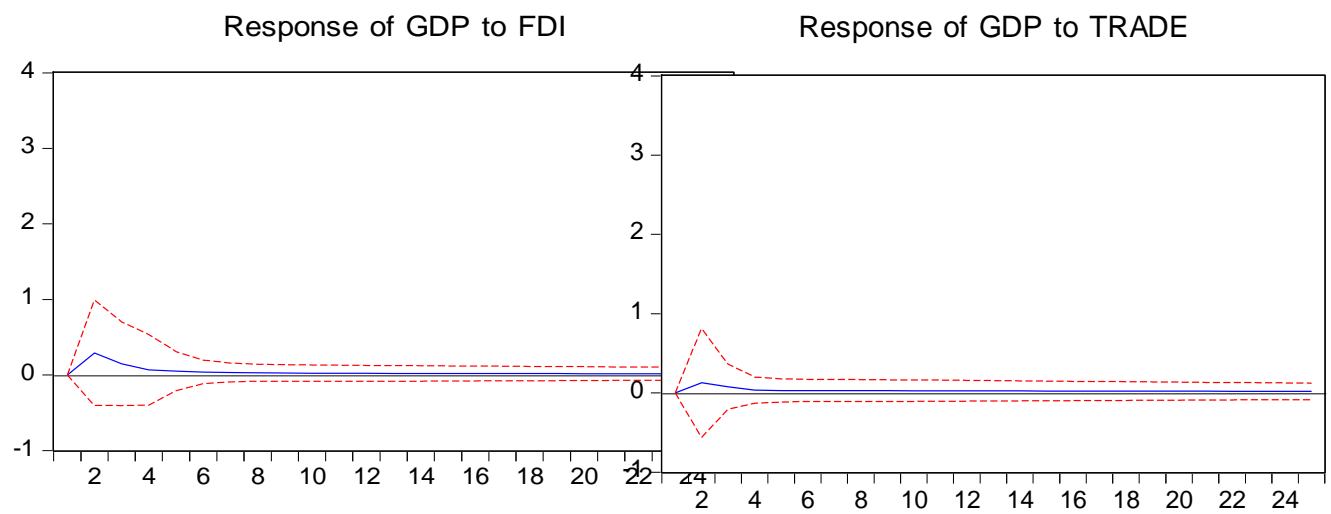

Gambar 5. Hasil Implus Respons Factor (IRF)

Pada estimasi impulse response diatas, respon GDP terhadap shock variabel FDI menunjukkan bahwa respon GDP terhadap FDI bersifat fluktuatif. Pada periode pertama sampai periode ke 2 terlihat bahwa variabel GDP memberikan respon positif terhadap FDI sebesar 0,2 \%. Pada periode selanjutnya, respon GDP terhadap shock FDI mulai menurun namun tidak sampai kearah negatif hingga kisaran $0,02 \%$. Respon tersebut akan mencapai titik keseimbangan pada periode ke- 8 sampai periode 22 dengan respon sebesar $0.001 \%$. Hal tersebut mengindikasikan dalam jangka panjang terdapat hubungan positif antara GDP terhadap FDI. Sedangkan berdasarkan hasil impulse response respon GDP terhadap shock TRADE menunjukkan bahwa respon GDP terhadap shock TRADE positif dan meningkat pada periode ke 2 yakni sebesar $0.1 \%$, namun pada periode berikutnya respon GDP terhadap TRADE mulai menurun sampai kisaran 0,001\% pada periode ke 3 hingga mencapai keseimbangan pada periode ke 4 sampai periode ke 24 . Hal tersebut mengindikasikan dalam jangka panjang terdapat hubungan positif antara GDP dengan TRADE.

Analisis Variance Decomposition (VD) merupakan analisis untuk memprediksi kontribusi varians variabel karena perubahan variabel tertentu dalam model VAR.Dengan analisis ini akan diketahui berapa kontribusi variabel FDI karena perubahan variabel GDP pada masing-masing periode dan berapa kontribusi variabel GDP karena perubahan variabel FDI pada masing-masing periode serta berapa kontribusi variabel GDP karena perubahan variabel TRADE. Uji VD diperluan untuk menguji perkiraan error variance suatu variabel yakni seberapa besar variance sebelum dan sesudah shock, baik shock yang berasal dari diri sendiri maupun dari variabel lain. 
Tabel 6. Hasil Output Variance Decomposition (DC) Of FDI, GDP and Trade

\begin{tabular}{lrlll}
\hline Period & \multicolumn{1}{r}{ S.E. } & \multicolumn{1}{c}{ GDP } & \multicolumn{1}{c}{ FDI } & \multicolumn{1}{c}{ TRADE } \\
\hline 1 & 3.379452 & 100 & 0 & 0 \\
2 & 3.545851 & 99.54319 & 0.418096 & 0.038712 \\
3 & 3.579488 & 97.68603 & 0.59725 & 1.716723 \\
4 & 3.613679 & 97.28397 & 0.602202 & 2.113825 \\
5 & 3.621565 & 96.98103 & 0.825978 & 2.192987 \\
6 & 3.624868 & 96.85161 & 0.82853 & 2.319863 \\
7 & 3.626995 & 96.84762 & 0.832439 & 2.319943 \\
8 & 3.627606 & 96.82782 & 0.849818 & 2.322359 \\
9 & 3.628028 & 96.80789 & 0.849762 & 2.342345 \\
10 & 3.628233 & 96.80244 & 0.852318 & 2.34524 \\
11 & 3.62848 & 96.79078 & 0.857015 & 2.3522 \\
12 & 3.62872 & 96.77853 & 0.859404 & 2.362071 \\
13 & 3.628946 & 96.76863 & 0.862947 & 2.368421 \\
14 & 3.629187 & 96.75778 & 0.866858 & 2.375358 \\
15 & 3.629428 & 96.7468 & 0.87026 & 2.382937 \\
\hline
\end{tabular}

Sumber : Hasil Olahan Eviews 7

Berdasarkan hasil Variance Decomposition diatas menunjukkan kontribusi terbesar terletak pada variabel GDP. Kontribusi variabel GDP terus menurun hingga periode ke 15 namun tetap positif dan paling dominan diantara variabel yang lain. Pada periode ke 3 kontribusi GDP mengalami penurunan yakni dari 99,54\% menjadi 97,68\%, walaupun trendnya menurun kontribusi GDP hingga periode ke 15 tetap positif dan paling dominan diantara variabel yang lain, hingga periode ke 15 kontribusi GDP sebesar 96,74\%. Kontribusi terbesar ke 2 dalam mempengaruhi pertumbuhan ekonomi yaitu variabel TRADE, varians pada variabel TRADE terus mengalami kenaikan sampai akhir periode, peningkatan tertinggi terletak pada akhir periode 15 yakni sebesar $2,38 \%$. Kontribusi varians pada variabel FDI dalam mempengaruhi pertumbuhan ekonomi juga mengalami trend yang positif, mulai dari awal periode hingga akhir periode, hal ini ditandai dengan nilai varians awal periode ke 2 sebesar $0,41 \%$ meningkat sampai akhir periode sebesar $0,87 \%$.

Berdasarkan hasil uji Granger Causality menunjukkan tidak ada hubungan 2 arah antara FDI dan GDP hal ini sesuai penelitian Dritsaki dan Stiakakis (2014), Temiz dan Gokmen (2014). Tidak adanya hubungan antara FDI dengan pertumbuhan ekonomi di 5 negara ASEAN (Indonesia, Malaysia, Filipina, Thailand dan Vietnam) disebabkan uji Granger Causality melihat hubungan 2 arah antara FDI dengan GDP dan sebaliknya maka estimasi dilanjutkan menggunakan metode VECM untuk melihat hubungan jangka panjang antara FDI dan GDP, TRADE dan GDP.Berdasarkan hasil estimasi VECM menunjukkan respon GDP terhadap shock FDI memberikan respon yang positif dan meningkat pada periode ke 2 dan periode selanjutnya mengalami penurunan dan cenderung stabil hingga akhir periode ke 24, Hal ini mengindikasikan dalam jangka panjang terdapat hubungan positif antara GDP dengan FDI, sesuai dengan penelitian Tekin, 2012; Lamsiraroj dan Ulubasoglu, 2015; Ibrahiem, 2015; Khatun dan Ahamad, 2015; Abdouli dan Hammami, 2016, De Mello (1999); Sunde, 2017 ; Abbes, dkk, 2015; Diby, 2014 dan Nistor, 2014.

Abdouli dan Hammami, 2016 menjelaskan bahwa Arus modal internasional yang masuk kedalam negeri terutama negara berkembang sebagai host country mampu membawa banyak pengaruh 
positif baik bersifat financial maupun non-financial. Selain sebagai pelengkap investasi domestik, bagi host country FDI akan membawa pengaruh positif lainnya seperti mempercepat transmisi teknologi modern dan pengembangan human capital sehingga tingkat produktivitas domestik meningkat dan kebutuhan masyarakat dapat terpenuhi,hal tersebut jelas akan meningkatkan pertumbuhan ekonomi dari sisi GDP. Jika dilihat dari karakteristik ke 5 negara ASEAN yaitu Indonesia, Malaysia, Thailand, Vietnam dan Filipina, ke 5 negara ASEAN tersebut memiliki karakteristik yang hampir sama, yaitu sama-sama negara berkembang dengan basis utama sektor pertanian, negara ASEAN 5 tersebut juga memiliki perekonomian terbuka. Sesuai dengan hasil IRF ketika ada guncangan dari FDI langsung di renspon oleh perubahan pertumbuhan ekonomi. hal ini tentunya sesuai dengan pendapat Dornbusch, Fisher dan Strartz : 2004 yang menyatakan pertumbuhan ekonomi berhubungan dengan pertumbuhan dalam input seperti tenaga kerja dan modal, dan perbaikan dalam teknologi, Dornbusch, Fisher dan Strartz (2004) juga berpendapat jika FDI meningkat lantas akan direspon cepat oleh pertumbuhan ekonomi,hal tersebut terjadi di 5 negara ASEAN tersebut, naik turunnya FDI selalu memberikan perubahan terhadap pertumbuhan ekonomi.

Sedangkan berdasarkan hasil impulse response respon GDP terhadap shock TRADE menunjukkan bahwa respon GDP terhadap shock TRADE positif dan meningkat pada periode ke 2 namun pada periode berikutnya respon GDP terhadap TRADE mulai menurun sampai pada periode ke 3 hingga mencapai keseimbangan pada periode ke 4 sampai periode ke 24, hal ini mengindikasikan bahwa setiap kenaikan/penurunan GDP akan direspon dengan kenaikan/penurunan TRADE begitupun sebaliknya setiap kenaikan/penurunan TRADE akan direspon oleh kenaikan/penurunan GDP, hal tersebut sesuai dengan penelitian Belloumi (2014). Hoang (2012) berpendapat dengan adanya trade openness yang tinggi, yang menyebabkan trade barrier semakin menurun ini merupakan suatu kesempatan bagi investor asing untuk dapat memanfaatkan keunggulan komparatif host country tersebut untuk dapat melakukan reexport sehingga akan menaikkan pertumbuhan ekonomi dari sisi GDP. Di negara berkembang khususnya ASEAN 5 (Indonesia, Vietnam, Malaysia, Thailand dan Filipina) mempunyai keunikan dalam diversifikasi produk. Basis sektor pertanian selalu menjadi keunggulan khususnya di Indonesia, Vietnam dan Thailand, dengan menerapkan trade openness yang tinggi akan menyebabkan keterbukaan dengan beberapa negara lain sehingga spesialisasi produk dapat terjadi.

Kebijakan trade openness yang tinggi di negara ASEAN 5 sangat kondusif meningkatkan transaksi perdagangan internasional baik melalui pemberlakuan tarif maupun kuota. Dengan demikian kebijakan pemerintah untuk melaksanakan berbagai kebijakan perdagangan internasional yang bertujuan untuk meningkatkan nilai trade openness dengan membuka ruang seluas-luasnya bagi lalu lintas perdagangan antar negara merupakan langkah yang tepat untuk dilakukan negaranegara Asean 5. Hal ini penting dilakukan karena trade openness memberikan dampak yang sangat besar terhadap upaya peningkatan pertumbuhan ekonomi yang lebih baik dan cepat. Adanya kebijakan ekspor dan impor dengan suatu sistem yang baru dan produktif sangat memungkinkan dilakukan pemerintah negara-negara Asean untuk memacu pertumbuhan ekonomi dan mengejar ketertinggalan dari negara-negara maju. Dan sosialisasi peraturan pemerintah dalam bidang perdagangan antar negara perlu dilakukan, di mana masyarakat/pelaku perdagangan internasional agar sepenuhnya memahami secara baik peraturan yang dikeluarkan pemerintah. Kondisi tersebut memungkinkan pelaku usaha dapat menentukan bidang usaha yang sesuai untuk dilakukan sehingga trade openness secara jangka panjang dapat terus mendorong pertumbuhan ekonomi.

\section{KESIMPULAN}

Berdasarkan uji Granger Causality tidak terdapat hubungan antara FDI terhadap GDP dan sebaliknya antara GDP terhadap FDI, tidak terdapat hubungan antara trade openness terhadap GDP dan sebaliknya antara GDP terhadap trade openness. Berdasar uji VECM terdapat hubungan antara FDI terhadap GDP dan trade oppeness terhadap GDP. 


\section{DAFTAR PUSTAKA}

Abbes, S. M., e. a. (2015). Causal Interactions between FDI, and Economic Growth: Evidence from Dynamic Panel Co-integration. Procedia Economics and Finance, 276-290.

Abdouli, M. \&. (2016). Investigating the causality links between environmental quality, foreign direct investment and economic growth in MENA countries. International Business Review, 264-278.

Agenor, P. R. (2001). Benefits and Costs of International Financial Integration: Theory and Facts. Policy Research Working Paper, 2699.

Agustus, T. .. (2017, December 1). Data Pertumbuhan Ekonomi ASEAN. Retrieved Agust 2, 2018, from Tradingeconimics website: http://www.tradingeconomics.com

Almfraji. M A, A. M. (2014). Economic Growth and Foreign Direct Investment Inflows: The Case of Qatar. Procedia - Social and Behavioral Sciences, 1040-1045.

Azwar, S. (2001). Metode Penelitian. Yogyakarta: Pustaka Pelajar Offset .

Belloumi, M. (2014). The relationship between trade, FDI and economic growth in Tunisia: An application of the autoregressive distributed lag model. Economic Systems, 269-287.

Borensztein. E, G. J.-W. (1998). How does foreign direct investment affect economic growth? Journal of International Economics , 115-135.

De Mello, J. L. (1999). FDI-led growth: evidence from time series and panel data. Oxford Economic Papers , 133-151.

Diby, S. L. (2014). Impact of foreign direct investments on economic growth in Africa: Evidence from three decades of panel data analyses. Research in Economics, 248-256.

Dornbusch, R. F. (2004). Makroekonomi. Jakarta: PT.Media Global Edukasi Jakarta.

Dritsaki, C. E. (2014). Foreign Direct Investments, Exports, and Economic Growth in Croatia: A Time Series Analysis. Procedia Economics and Finance, 181-190.

Greene, W. H. (2002). Econometric Analysis Fifth Edition Prentice Hall. New Jersey The united States Of Amerika.

Gujarati, D. (1995). Basic Econometrics, Fourth Edition. The McGraw-Hill Companies.

Hoang, H. H. (2012). Foreign Direct Investment in Southeast Asia; Determinants and Spatial Distributin. Centre of Studies and Research on International Development (CERDI) University of Auvergne, CNRS, 10-20.

Ibrahiem, D. M. (2015). Renewable Electricity Consumption, Foreign Direct Investment and Economic Growth in Egypt: An ARDL Approach. Procedia Economics and Finance, 313323.

Khatun, F. \&. (2015). Foreign direct investment in the energy and power sector in Bangladesh: Implications for economic growth. Renewable and Sustainable Energy Reviews, 13691377.

Krugman, P. \&. (1999). Ekonomi Internasional: Teori dan Kebijakan. Jakarta: PT Raja Grafindo.

Kurniawan, P. B. (2015). Pengantar Ekonomi Mikro dan Makro. Yogyakarta: CV. Andi Offset .

Lamsiraroj, S. \&. (2015). Foreign direct investment and economic growth: A real relationship or wishful thinking? Economic Modelling, 200-213.

Lindert, P. H. (1994). Ekonomi Internasional Edisi kesembilan cetakan 1. Jakarta: Bumi Aksara.

Mahyus, E. (2016). Analisis Ekonometrika Time Series Edisi Kedua. Jakarta: Mitra Wacana Media.

Mankiw, G. (2006). Makroekonomi. Jakarta: Erlangga.

Mankiw, N. G. (2014). Pengantar Ekonomi Makro Edisi Asia. Jakarta: Salemba Empat.

Nistor, P. (2014). FDI and Economic Growth, the Case of Romania. Procedia Economics and Finance, 577-582.

Richard, L. (1995). Pengantar Ekonomi Mikro (Terjemahan). Jakarta: Binarupa Aksara.

Rodrik, D. R. (2010). Handbook Of Development Economics. North-Holland .

Tafirenyika, S. (2017). Foreign direct investment and economic growth: ADRL and causality analysis for South Africa. Research in International Business and Finance, 11-17.

Tekin, R. B. (2012). Economic growth, exports and foreign direct investment in Least Developed Countries: A panel Granger causality analysis. Economic Modelling, 868-878. 
Temiz, D. G. (2014). FDI inflow as an international business operation by MNCs and economic growth: An empirical study on Turkey. International Business Review, 145-154.

Todaro, M. (2000). Ekonomi Pembangunan Edisi ke 6. Jakarta: Erlangga.

Todaro, M. P. (2011). Pembangunan Ekonomi Edisi Kesebelas. Jakarta: Erlangga.

Yaqin su, Z. L. (2015). The impact of foreign direct investment and human capital on economic growth: Evidence from Chinese cities. China Economic Review, 97-10. 